\title{
Preliminary study on lipid extraction from Nannochloropsis salina using supercritical carbon dioxide method
}

\author{
Nur Hidayah Zainan a, b, Mohd. Azizi Che Yunus c ${ }^{c}$, Razif Harun a, ${ }^{*}$ \\ a Department of Chemical and Environmental Engineering, Universiti Putra Malaysia (UPM), 43400, Serdang, Malaysia \\ b Department of Biotechnology Engineering, International Islamic University Malaysia (IIUM), 53100, Gombak, Kuala Lumpur \\ c Centre of Lipids Engineering and Applied Research (CLEAR), Ibnu Sina Institute for Scientific \& Industrial Research (Ibnu Sina ISIR), Universiti \\ Teknologi Malaysia, 81310 UTM Johor Bahru, Johor \\ *Coresponding author : mh_razif@upm.edu.my
}

Article history

Received 28 Mac 2018

Revised 20 May 2018

Accepted 3 July 2018

Published Online 3 September 2018

\section{Graphical abstract}

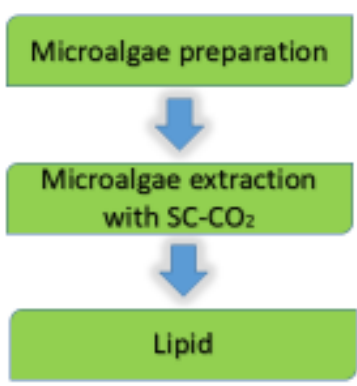

\begin{abstract}
The issues involved with conventional lipid extraction methods, such as the usage of toxic solvents and accumulation of chemical waste, has motivated researchers to find an alternative approach to the extraction technology. One of the alternatives is via the Supercritical Carbon Dioxide ( $\left.\mathrm{SC}-\mathrm{CO}_{2}\right)$ method. This extraction method is considered as green as it provides a clean, selective and efficient process. Although the $\mathrm{SC}-\mathrm{CO}_{2}$ method has been successfully used to extract lipids from microalgae, there are still some issues related to sample preparation and process parameters that need to be resolved. Therefore, this study investigates the effect of adding a modifier (ethanol) and using different types of holders (cotton and steam bun cloth) has on the yield of lipid from Nannochloropsis salina. The usage of a holder is required during the process due to the fine particles of the microalgae which have the potential to clog the instrument used. The $\mathrm{SC}-\mathrm{CO}_{2}$ extraction without the modifier was conducted for 4 hours at $60^{\circ} \mathrm{C}, 30 \mathrm{MPa}$ and $\mathrm{CO}_{2}$ flow rate of $4 \mathrm{ml} / \mathrm{min}$, while the extraction with the modifier was conducted using $3.8 \mathrm{ml} / \mathrm{min} \mathrm{CO}_{2}$ and $0.2 \mathrm{ml} / \mathrm{min}$ ethanol. It was found that the highest lipid yield of $0.16 \mathrm{~g}$ lipid $/ \mathrm{g}$ dried microalgae was achieved using cotton cloth as a holder with the addition of the modifier. Lower amount of lipids were obtained when using the Soxhlet method $(0.08 \mathrm{~g}$ lipid / $\mathrm{g}$ dried microalgae) and SC- $\mathrm{CO}_{2}$ without modification ( $0.02 \mathrm{~g}$ lipid / $\mathrm{g}$ dried microalgae). These preliminary findings show that the $\mathrm{SC}-\mathrm{CO}_{2}$ process requires modifications to enhance the lipids yield from microalgae.
\end{abstract}

Keywords: Microalgae, supercritical carbon dioxide, extraction, lipid, tablet

\section{INTRODUCTION}

Microalgae contains protein, carbohydrate and lipid compounds which can be further converted into various products such as animal feed, bioethanol and biodiesel [1]. However, the high cultivation cost of microalgae makes it an unfeasible feedstock for the above applications [2]. Hence, researchers are now switching their interest into bioactive compounds that are present in microalgae such as polyunsaturated fatty acids (PUFAs) that are essential and valuable for humans.

PUFAs contain omega- 3 and omega- 6 . The omega- 3 and omega- 6 are present in the lipids which are located in the microalgae's cells. The toughness of the cell walls of the microalgae makes the lipids are not easily accessible and the omega- 3 and omega- 6 are sometimes subjected to thermodegradation under harsh operating conditions [3]. Therefore, it is of value to find a suitable technology to extract the lipids $[4,5]$ from the microalgae. Mechanical and chemical extraction techniques have been used in the past to extract lipid from microalgae. However, questions have been raised about the use of these technologies as they have failed to give good quality products, as well as the presence of organic solvents which are not suitable for human consumption [6]. The issues mentioned above have spurred the efforts in discovering other extraction technologies which are clean, selective and efficient.

Supercritical Carbon Dioxide $\left(\mathrm{SC}-\mathrm{CO}_{2}\right)$ extraction can play an essential role in addressing the issues of conventional extraction. In SC-
$\mathrm{CO}_{2}$, fluid is pressurized to a certain temperature which is above its critical level condition. Carbon dioxide $\left(\mathrm{CO}_{2}\right)$ is the most common fluid used by researchers and industries due to its unique characteristics. $\mathrm{CO}_{2}$ is non-toxic, non-flammable, economical and easily separated from the extracts after the extraction process as $\mathrm{CO}_{2}$ is a gas at room temperature [3]. Thus far, lipids have been obtained from various algae such as Crypthecodinium cohnii, Hypnea charoides, Nannochloropsis sp., Scenedesmus obliquus, Chlorella protothecoides, Nannochloropsis salina, Spirulina plantesis, Arthrospira platensis, Botryococcus braunii, Chlorella vulgaris, Dunaliella salina, and Nannochloropsis gaditana using $\mathrm{SC}-\mathrm{CO}_{2}[3,7-13]$. Although studies have been carried out on the $\mathrm{SC}-\mathrm{CO}_{2}$ of microalgae, there are still many issues that need to be considered such as microalgae strains, sample preparation, operating conditions, product yield, process efficiency and economic viability.

This preliminary study was conducted to observe the effects of modifier addition (ethanol) and the usage of different types of microalgae holders (cotton and steam bun cloth) on the yield of lipid. The holder is required during the process due to the fine particles of the microalgae which have the potential to clog the instrument. One way of overcoming this limitation (clogging by fine particles) is by compressing the microalgae into a tablet. Hence, it is of interest to observe the lipid yield from the microalgae tablet without being supported by any holder. 


\section{EXPERIMENTAL}

\section{Materials}

The microalgae Nannochloropsis salina (N. salina) powder was obtained from Xi'an Lyphar Biotech Co., LTD. The average particle size of the microalgae was $60-100 \mu \mathrm{m}$. The microalgae $N$. salina tablet was formed by compressing the microalgae powder using the Universal Instron Testing Machine 5566 (Instron, US). The force that was used to compress the microalgae powder was $8 \mathrm{kN}$ and the microalgae tablet weight was $0.1 \pm 0.05 \mathrm{~g}$. The diameter of the microalgae tablet was 13 $\mathrm{mm}$. Carbon dioxide $\left(\mathrm{CO}_{2}\right)$ of $99 \%$ purity, contained in a cylinder, was supplied by Kras Instrument and Services, Johor. Hexane was purchased from R\&M Chemicals and the ethanol (100\%) used in this study was from Hayman.

\section{Lipid extraction by Soxhlet extraction method}

The Soxhlet extraction method was conducted using $5 \mathrm{~g}$ of microalgae and hexane was used as a solvent. The solvent was heated and the extraction was carried out for 8 hours. After the extraction, the hexane was evaporated and the lipid obtained was gravimetrically determined.

\section{Lipid extraction using $\mathrm{SC}-\mathrm{CO}_{2}$ with the presence of holders}

The $\mathrm{SC}-\mathrm{CO}_{2}$ experiment was conducted using a set of laboratory scale supercritical extractors which consisted of a $\mathrm{CO}_{2}$ cylinder, $\mathrm{CO}_{2}$ pump, modifier pump, oven and back pressure regulator (BPR) (Jasco, Model BP-2080). Fig. 1 shows the schematic diagram of the $\mathrm{SC}-\mathrm{CO}_{2}$ used in this study. About $2 \mathrm{~g} \pm 0.5$ of microalgae was used and the microalgae were put in a holder (cotton and steam bun cloth). The holder that contained the microalgae was fitted into the vessel and the vessel was then placed in the oven. The desired pressure and temperature was set at the BPR and the oven. Once the desired temperature was reached, the $\mathrm{CO}_{2}$ cylinder valve was opened. The $\mathrm{CO}_{2}$ and modifier pump were turned on once the BPR reached a stable pressure. The starting time was when the extract began to flow into the collection vial. The collection vial was changed every 30 minutes. The study was conducted for 4 hours. The parameters of the experiments in this study are as follows;

Sample 1: $60^{\circ} \mathrm{C}, 30 \mathrm{MPa}, 4.0 \mathrm{ml} / \mathrm{min} \mathrm{CO}_{2}$ and cotton cloth Sample 2: $60^{\circ} \mathrm{C}, 30 \mathrm{MPa}, 3.8 \mathrm{ml} / \mathrm{min} \mathrm{CO}_{2}, 0.2 \mathrm{ml} / \mathrm{min}$ ethanol and cotton cloth

Sample 3: $60^{\circ} \mathrm{C}, 30 \mathrm{MPa}, 3.8 \mathrm{ml} / \mathrm{min} \mathrm{CO}_{2}, 0.2 \mathrm{ml} / \mathrm{min}$ ethanol and steam bun cloth

Sample 4: $60^{\circ} \mathrm{C}, 30 \mathrm{MPa}, 4.0 \mathrm{ml} / \mathrm{min} \mathrm{CO}_{2}$ and steam bun cloth
The lipid obtained was determined gravimetrically by weighing the collection vial before and after extraction.

$$
\begin{array}{r}
\text { Lipid weight }=\text { Weight of collection vial with lipid } \\
- \text { Weight of collection vial }
\end{array}
$$

\section{Cumulative lipid weight}

$=$ Addition of lipid weight after every 30 minutes

$$
\text { Lipid yield }=\begin{gathered}
\text { Cumulative lipid weight }(g) \\
\text { Microalgae weight }(g)
\end{gathered}
$$

\section{Lipid extraction of microalgae tablet using $\mathrm{SC}-\mathrm{CO}_{2}$}

About $1.0 \pm 0.5 \mathrm{~g}$ of microalgae tablet was directly placed in the vessel without any holder and the experimental setup was similar to the previous experiment $\left(60^{\circ} \mathrm{C}, 30 \mathrm{MPa}, 4 \mathrm{ml} / \mathrm{min} \mathrm{CO}_{2}\right)$. The lipid obtained in this study was gravimetrically determined.

\section{RESULTS AND DISCUSSION}

\section{Effect of microalgae holder and modifier on the yield of lipid}

Table 1 and Fig. 2 show the results of lipid weight, cumulative lipid weight and lipid yield obtained from $\mathrm{SC}-\mathrm{CO}_{2}$ of $N$. salina using different holders (cotton and steam bun cloth) in the presence and absence of modifiers. A higher yield of lipid was observed when the modifier was added during the $\mathrm{SC}-\mathrm{CO}_{2}$. About $0.16 \mathrm{~g}$ lipid / g dried microalgae were obtained when cotton cloth was used as a holder whilst around $0.07 \mathrm{~g}$ lipid / $\mathrm{g}$ dried microalgae was obtained with the steam bun cloth. The results indicate that the holders used in this study affected the yield of lipid in the presence of the modifier. In contrast, there were only about $0.02 \mathrm{~g}$ lipid / g dried microalgae extracted with the $\mathrm{SC}-\mathrm{CO}_{2}$ without modifier irregardless of the holder used. The lipids

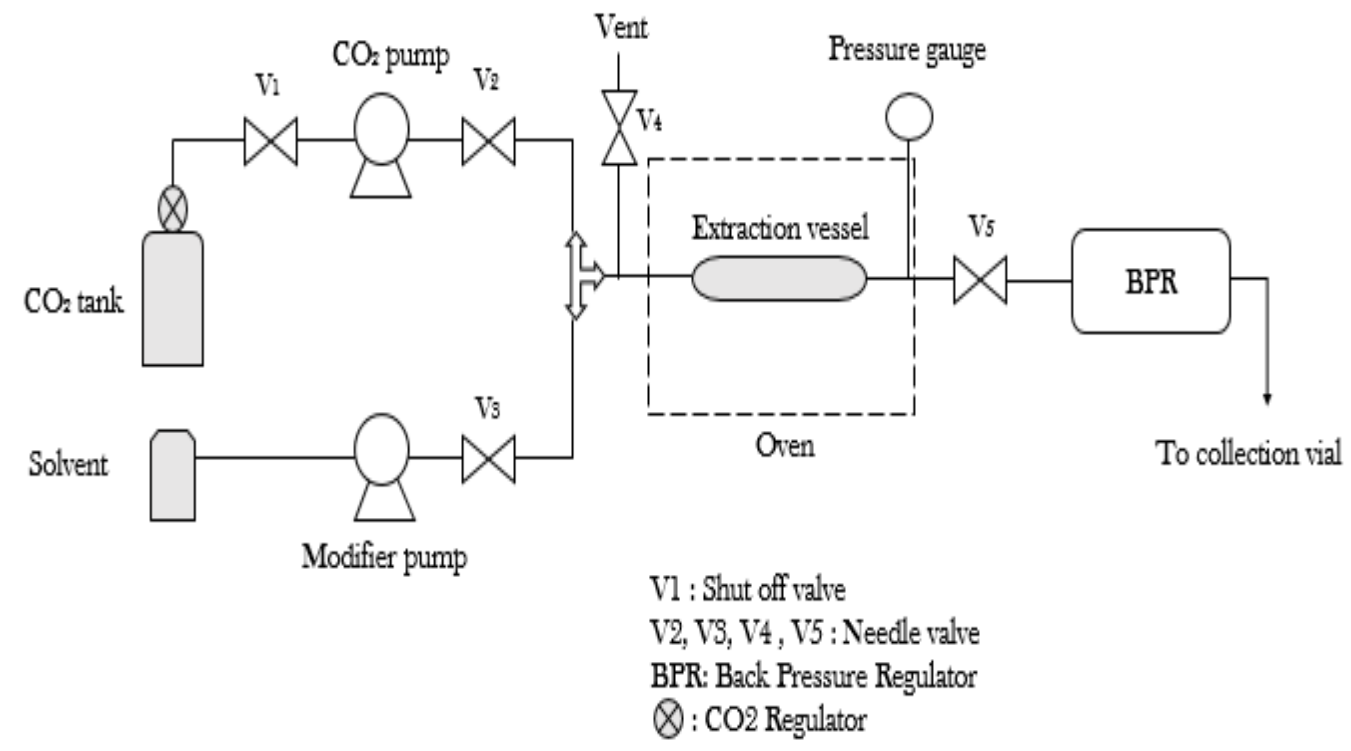

Fig.1 Schematic diagram of $\mathrm{SC}-\mathrm{CO}_{2}$ setup. 
Table 1 Lipid and cumulative lipid weight of microalgae N. salina after extraction

Sample 1: $60^{\circ} \mathrm{C}, 30 \mathrm{MPa}, 4.0 \mathrm{ml} / \mathrm{min} \mathrm{CO}_{2}$ and $2.0179 \mathrm{~g}$ microalgae in cotton cloth

\begin{tabular}{ccccc}
$\begin{array}{c}\text { Time } \\
(\mathbf{m i n})\end{array}$ & $\begin{array}{c}\text { Empty } \\
\text { vial }(\mathbf{g})\end{array}$ & $\begin{array}{c}\text { Empty vial } \\
\text { +lipid (g) }\end{array}$ & Lipid (g) & $\begin{array}{c}\text { Cumulative } \\
\text { lipid (g) }\end{array}$ \\
\hline 30 & 12.5028 & 12.5164 & 0.0136 & 0.0136 \\
60 & 12.1442 & 12.156 & 0.0118 & 0.0254 \\
90 & 12.2262 & 12.228 & 0.0018 & 0.0272 \\
120 & 12.5509 & 12.552 & 0.0011 & 0.0283 \\
150 & 12.4047 & 12.4068 & 0.0021 & 0.0304 \\
180 & 12.3219 & 12.3249 & 0.003 & 0.0334 \\
210 & 12.4123 & 12.4149 & 0.0026 & 0.036 \\
240 & 12.5091 & 12.5129 & 0.0038 & 0.0398 \\
\hline
\end{tabular}

Sample 2: $60^{\circ} \mathrm{C}, 30 \mathrm{MPa}, 3.8 \mathrm{ml} / \mathrm{min} \mathrm{CO}_{2}, 0.2 \mathrm{ml} / \mathrm{min}$ ethanol and $2.0363 \mathrm{~g}$ microalgae in cotton cloth

\begin{tabular}{ccccc}
$\begin{array}{c}\text { Time } \\
(\mathbf{m i n})\end{array}$ & $\begin{array}{c}\text { Empty } \\
\text { vial }(\mathbf{g})\end{array}$ & $\begin{array}{c}\text { Empty vial } \\
\text { +lipid }(\mathbf{g})\end{array}$ & Lipid (g) & $\begin{array}{c}\text { Cumulative } \\
\text { lipid }(\mathbf{g})\end{array}$ \\
\hline 30 & 6.115 & 6.1745 & 0.0595 & 0.0595 \\
60 & 6.0109 & 6.0957 & 0.0848 & 0.1443 \\
90 & 6.1248 & 6.1792 & 0.0544 & 0.1987 \\
120 & 6.1276 & 6.1629 & 0.0353 & 0.234 \\
150 & 6.0161 & 6.043 & 0.0269 & 0.2609 \\
180 & 6.167 & 6.1918 & 0.0248 & 0.2857 \\
210 & 6.177 & 6.1975 & 0.0205 & 0.3062 \\
240 & 6.0443 & 6.065 & 0.0207 & 0.3269 \\
\end{tabular}

Sample 3: $60^{\circ} \mathrm{C}, 30 \mathrm{MPa}, 3.8 \mathrm{ml} / \mathrm{min} \mathrm{CO}_{2}, 0.2 \mathrm{ml} / \mathrm{min}$ ethanol, and $2.0955 \mathrm{~g}$ microalgae in steam bun cloth

\begin{tabular}{ccccc}
$\begin{array}{c}\text { Time } \\
(\mathbf{m i n})\end{array}$ & $\begin{array}{c}\text { Empty } \\
\text { vial }(\mathbf{g})\end{array}$ & $\begin{array}{c}\text { Empty vial } \\
\text { +lipid (g) }\end{array}$ & Lipid (g) & $\begin{array}{c}\text { Cumulative } \\
\text { lipid }(\mathbf{g})\end{array}$ \\
\hline 30 & 4.7766 & 4.8076 & 0.031 & 0.031 \\
60 & 4.894 & 4.9288 & 0.0348 & 0.0658 \\
90 & 4.8534 & 4.8717 & 0.0183 & 0.0841 \\
120 & 4.781 & 4.7916 & 0.0106 & 0.0947 \\
150 & 4.7628 & 4.7654 & 0.0026 & 0.0973 \\
180 & 4.8434 & 4.8463 & 0.0029 & 0.1002 \\
210 & 4.9127 & 4.9304 & 0.0177 & 0.1179 \\
240 & 4.7758 & 4.8013 & 0.0255 & 0.1434 \\
\hline
\end{tabular}

Sample 4: $60^{\circ} \mathrm{C}, 30 \mathrm{MPa}, 4.0 \mathrm{ml} / \mathrm{min} \mathrm{CO}_{2}$, and $2.0655 \mathrm{~g}$ microalgae in

\begin{tabular}{ccccc}
\hline $\begin{array}{c}\text { Time } \\
(\mathbf{m i n})\end{array}$ & $\begin{array}{c}\text { Empty } \\
\text { vial }(\mathbf{g})\end{array}$ & $\begin{array}{c}\text { Empty vial } \\
\text { +lipid }(\mathbf{g})\end{array}$ & Lipid (g) & $\begin{array}{c}\text { Cumulative } \\
\text { lipid }(\mathbf{g})\end{array}$ \\
30 & 12.3732 & 12.386 & 0.0128 & 0.0128 \\
60 & 12.5298 & 12.5393 & 0.0095 & 0.0223 \\
90 & 12.2948 & 12.3019 & 0.0071 & 0.0294 \\
120 & 12.0827 & 12.0873 & 0.0046 & 0.034 \\
150 & 12.5004 & 12.5043 & 0.0039 & 0.0379 \\
180 & 12.306 & 12.3093 & 0.0033 & 0.0412 \\
210 & 12.2545 & 12.2575 & 0.003 & 0.0442 \\
240 & 12.1518 & 12.1553 & 0.0035 & 0.0477 \\
\hline
\end{tabular}

extracted from $N$. salina in this study were higher than the lipids obtained from microalgae Chlorococcum sp. (0.058 g lipid/g dried microalgae) [14] but lower than Nannochloropsis sp. (0.250 g lipid/g dried microalgae) and Botryococcus braunii ( $0.286 \mathrm{~g}$ lipid/g dried microalgae) $[8,15]$. The differences may be due to the different species used, experiment conditions (time, flow rate, pressure, presence and absence of modifier) and $\mathrm{SC}-\mathrm{CO}_{2}$ setup.

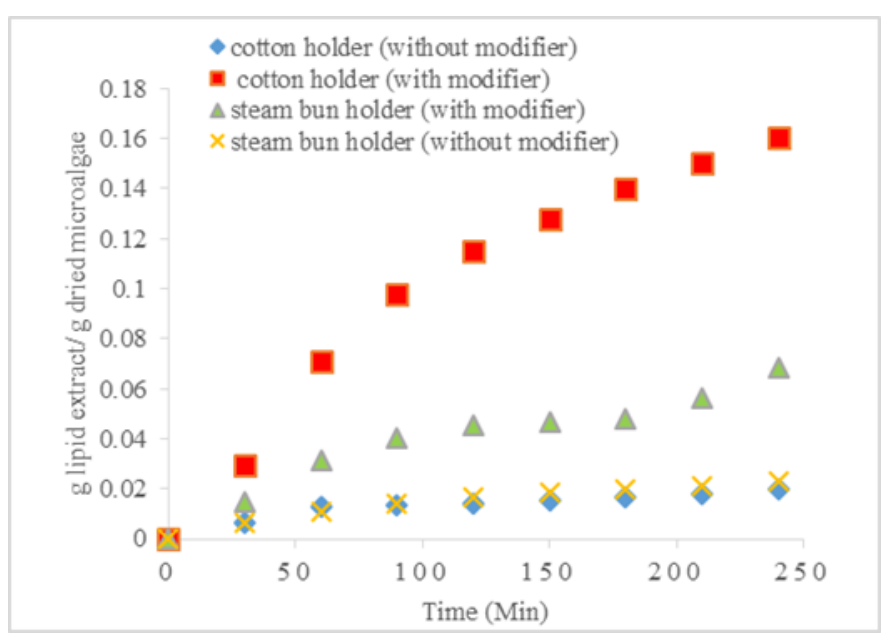

Fig. 2 Effect of holder and modifier on the yield of lipid extracted from SC- $\mathrm{CO}_{2}$ (The experiments without modifier were conducted at $60^{\circ} \mathrm{C}, 30$ $\mathrm{MPa}$ and $4 \mathrm{ml} / \mathrm{min} \mathrm{CO}_{2}$ while the experiments with modifier were conducted at $60^{\circ} \mathrm{C}, 30 \mathrm{MPa}$ and $3.8 \mathrm{ml} / \mathrm{min} \mathrm{CO}_{2}$ and $0.2 \mathrm{ml} / \mathrm{min}$ ethanol).

Moreover, the lipid extracted from $\mathrm{SC}-\mathrm{CO}_{2}$ without modifier was lower than the lipid obtained from $\mathrm{SC}-\mathrm{CO}_{2}$ with modifier due to the fact that $\mathrm{CO}_{2}$ is only able to extract non-polar lipid. Some lipids are polar and the $\mathrm{CO}_{2}$ alone are not sufficient enough to disrupt these lipids as it is strongly linked via hydrogen bonds [16]. Therefore, a polar solvent, such as ethanol (modifier), is required to disrupt these lipids [16]. Sapkale et al. [17] also reported that the addition of modifier to the solvent could increased the matrix swelling hence maximizing the diffusion of supercritical solvent into the matrix.

In this study, the extraction of lipid from microalgae began with the interaction of supercritical fluid $\left(\mathrm{CO}_{2}\right)$ with the microalgae $N$. salina. At this supercritical conditions, $\mathrm{CO}_{2}$ has some properties of a gas and some of a liquid. As a gas, it can diffuse into the microalgae cell and as a liquid, it could dissolve the lipids in the microalgae cell [18]. The dissolved lipids are then removed from the extraction vessel into a collection vial at lower pressure, and the extracted lipid settles out.

The use of the holder and thick cotton wool provides an extra resistance to the diffusion of dissolved lipids, causing a reduction in the lipid yield. A simple experiment was conducted to test the penetration of gas into the steam bun cloth and the gas was observed to be able to penetrate a layer of steam bun cloth. However, if the microalgae were covered by multiple layers of the cloth, the gas then failed to reach the microalgae. Hence, it can be deduced that the thickness and the type of materials affect the rate of extraction. Fig. 2 shows that the lipid yield still increased even after 4 hours of extraction. This is probably due to the microalgae that were not homogeneously distributed in the microalgae holder which resulted in the inconsistency of $\mathrm{CO}_{2}$ penetration into the microalgae cell.

The efficiency of the $\mathrm{SC}-\mathrm{CO}_{2}$ in this study was compared with the Soxhlet extraction method. It could be observed that only $8 \mathrm{wt} . \%$ of the extract was obtained after 8 hours via the Soxhlet method compared to 16 wt. \% of extract after 4 hours of extraction by $\mathrm{SC}-\mathrm{CO}_{2}$ as shown in Fig. 3. The results showed that $\mathrm{SC}-\mathrm{CO}_{2}$ yielded twice the amount of extract at half of the extraction time compared to Soxhlet. Halim et al. [14] also reported that $\mathrm{SC}-\mathrm{CO}_{2}$ is more efficient than hexane lipid extraction (Soxhlet). About $0.058 \mathrm{~g}$ lipid / $\mathrm{g}$ dried microalgae were obtained after 80 minutes of SC- $\mathrm{CO}_{2}$ extraction compared to 5.5 hours of Soxhlet extraction (0.032 g lipid extract/g dried microalgae) [14]. 


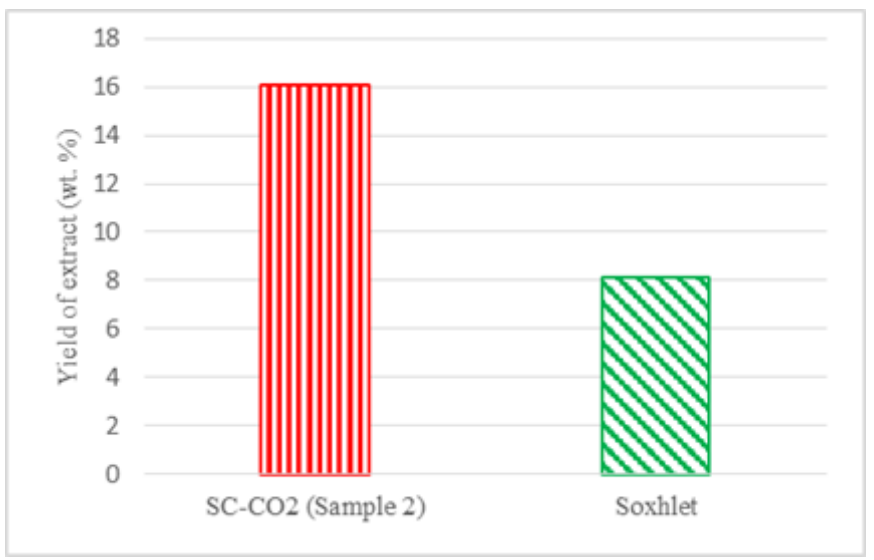

Fig. 3 Comparison of extracts obtained from SC- $-\mathrm{CO}_{2}$ (sample 2 after 4 hours) and Soxhlet extraction (after 8 hours).

\section{$\mathrm{SC}-\mathrm{CO}_{2}$ extraction of microalgae tablet}

The $\mathrm{SC}-\mathrm{CO}_{2}$ instrument used in this study was prone to clogging hence it is not suitable for fine particle samples such as microalgae powder. Microalgae tablets were used to overcome this limitation (clogging by fine particles). The fine particles of the microalgae were compressed into a tablet form which then directly placed into a vessel without a holder to increase the extraction rate. The experiment was conducted without a modifier to eliminate the use of solvents. It was found that the yield of lipids after 3 hours of extraction was $0.08 \mathrm{~g}$ lipid / $g$ of dried microalgae. The yield was quadruple that of the yield of lipid with the microalgae holder without a modifier $(0.02 \mathrm{~g}$ lipid/ $\mathrm{g}$ of dried microalgae). The color of the microalgae tablet had changed from dark green to light green after the extraction which indicated the extracted (light green) and non-extracted regions (dark green) (Fig. 4). Most of the microalgae tablets in the vessel remained in the tablet form. This showed that the tablets could withstand high pressure; hence, feasible to be used for $\mathrm{SC}-\mathrm{CO}_{2}$. The lipid yield obtained from this study was less than the the results of the optimization study conducted by Millao et al. [13] using pelletized microalgae Nannochloropsis gaditana ( $0.152 \mathrm{~g}$ oil/ $\mathrm{g}$ dried substrate). We believe that the yield of lipid from this study could be increased once we optimize the operating conditions.

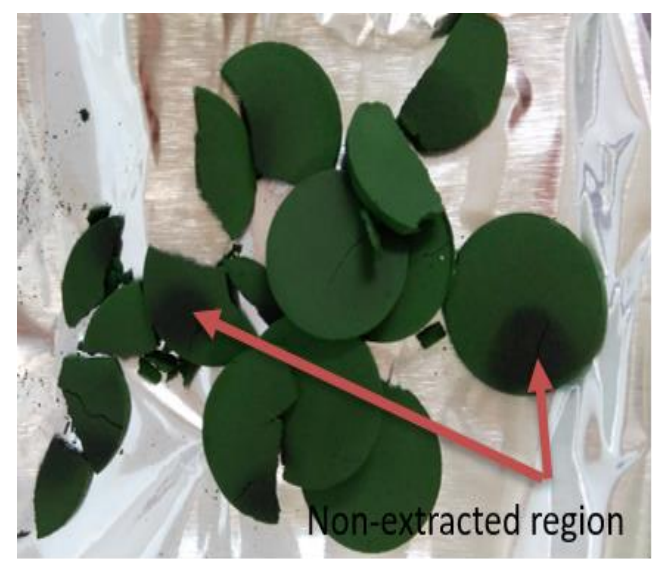

Fig. 4 Microalgae tablets after extraction.

\section{CONCLUSION}

Overall, we conclude that a suitable holder should be used for SC$\mathrm{CO}_{2}$ extraction. The addition of a modifier (ethanol) improves the lipid yield and the use of microalgae tablets seem very promising in the future as it gives a high yield of lipid as well as prevents clogging. Some of the experiments showed that the lipid yield obtained from $\mathrm{SC}-\mathrm{CO}_{2}$ was higher than the conventional extraction methods using a solvent (Soxhlet), hence proving the feasibility of $\mathrm{SC}-\mathrm{CO}_{2}$ to replace the conventional extraction methods. However, further research still needs to be conducted to determine the compounds of interest (PUFA-omega3 , EPA, and DHA).

\section{ACKNOWLEDGEMENT}

This work was financially supported by Universiti Putra Malaysia (Putra IPS Grant NO: 9573300). The authors would like to thank the Centre of Lipids Engineering and Applied Research (CLEAR), Ibnu Sina Institute for Scientific \& Industrial Research (Ibnu Sina ISIR), Universiti Teknologi Malaysia (UTM) for allowing the authors to use their Supercritical Carbon Dioxide Equipment for this research.

\section{REFERENCES}

[1] Harun, R., M. Singh, G. M. Forde, and M. K. Danquah, Bioprocess engineering of microalgae to produce a variety of consumer products. Renewable and Sustainable Energy Reviews, 2010. 14(3): p. 1037-1047.

[2] Santos-Sánchez, N. F., R. Valadez-Blanco, B. Hernández-Carlos, A. Torres-Ariño, P. C. Guadarrama-Mendoza, and R. Salas-Coronado, Lipids rich in $\omega-3$ polyunsaturated fatty acids from microalgae. Applied Microbiology and Biotechnology, 2016. 100(20): p. 8667-8684.

[3] Cheung, P. C. K., Temperature and pressure effects on supercritical carbon dioxide extraction of $\mathrm{n}-3$ fatty acids from red seaweed. Food Chemistry, 1999. 65: p. 399-403.

[4] Yen, H. -W., S. -C. Yang, C. -H. Chen, Jesisca, and J. -S. Chang, Supercritical fluid extraction of valuable compounds from microalgal biomass. Bioresource Technology, 2015. 184: p. 291-296.

[5] Lee, A. K., D. M. Lewis, and P. J. Ashman, Disruption of microalgal cells for the extraction of lipids for biofuels: Processes and specific energy requirements. Biomass and Bioenergy, 2012. 46: p. 89-101.

[6] Rai, A., B. Mohanty, and R. Bhargava, Modeling and response surface analysis of supercritical extraction of watermelon seed oil using carbon dioxide. Separation and Purification Technology, 2015. 141: p. 354-365.

[7] Solana, M., C. S. Rizza, and A. Bertucco, Exploiting microalgae as a source of essential fatty acids by supercritical fluid extraction of lipids: Comparison between Scenedesmus obliquus, Chlorella protothecoides and Nannochloropsis salina. The Journal of Supercritical Fluids, 2014. 92: p. 311-318.

[8] Andrich, G., U. Nesti, F. Venturi, A. Zinnai, and R. Fiorentini, Supercritical fluid extraction of bioactive lipids from the microalga Nannochloropsis sp. European Journal of Lipid Science and Technology, 2005. 107: p. 381-386.

[9] Couto, R. M., P. C. Simões, A. Reis, T. L. Da Silva, V. H. Martins, and Y. Sánchez-Vicente, Supercritical fluid extraction of lipids from the heterotrophic microalga Crypthecodinium cohnii. Engineering in Life Sciences, 2010. 10(2): p. 158-164.

[10] Crampon, C., C. Nikitine, M. Zaier, O. Lépine, C. D. Tanzi, M. A. Vian, F. Chemat, and E. Badens, Oil extraction from enriched Spirulina platensis microalgae using supercritical carbon dioxide. The Journal of Supercritical Fluids, 2017. 119: p. 289-296.

[11] Esquivel-Hernández, D. A., V. H. López, J. Rodríguez-Rodríguez, G. S. Alemán-Nava, S. P. Cuéllar-Bermúdez, M. Rostro-Alanis, and R. ParraSaldívar, Supercritical carbon dioxide and microwave-assisted extraction of functional lipophilic compounds from Arthrospira platensis. International Journal of Molecular Sciences, 2016. 17(5): p. 658.

[12] Mendes, R. L., B. P. Nobre, M. T. Cardoso, A. P. Pereira, and A. F. Palavra, Supercritical carbon dioxide extraction of compounds with pharmaceutical importance from microalgae. Inorganica Chimica Acta, 2003. 356: p. 328-334.

[13] Millao, S. and E. Uquiche, Extraction of oil and carotenoids from pelletized microalgae using supercritical carbon dioxide. The Journal of Supercritical Fluids, 2016. 116: p. 223-231.

[14] Halim, R., B. Gladman, M. K. Danquah, and P. A. Webley, Oil extraction from microalgae for biodiesel production. Bioresource Technology, 2011. 102(1): p. 178-185.

[15] Lee, J. -Y., C. Yoo, S. -Y. Jun, C. -Y. Ahn, and H. -M. Oh, Comparison of several methods for effective lipid extraction from microalgae. Bioresource Technology, 2010. 101(1, Supplement): p. S75-S77.

[16] Halim, R., M. K. Danquah, and P. A. Webley, Extraction of oil from microalgae for biodiesel production: A review. Biotechnology Advances, 2012. 30(3): p. 709-732.

[17] Sapkale, G. N., S. M. Patil, U. S. Surwase, and P. K. Bhatbhage, Supercritical fluid extraction - A review, International Journal of Chemical Sciences, 2010. 8(2): p. 729-743.

[18] Donato, P., P. Dugo, and L. Mondello, Separation of Lipids. In Fanali, S., P. Haddad, C. Poole, P. Schoenmakers, D. Llyod (Eds.) Liquid Chromatography Applications, 2013. USA: Elsevier, p. 203-248. 